\title{
DENSITY MANAGEMENT DIAGRAM FOR Eucalyptus grandis W. Hill. ex Maiden STANDS CONTROLLED BY DOMINANT HEIGHT
}

\author{
Gabriel Paes Marangon ${ }^{*}$, Emanuel Arnoni Costa², César Augusto Guimarães Finger ${ }^{3}$, Paulo Renato Schneider ${ }^{4}$, \\ Matheus Teixeira Martins ${ }^{1}$
}

${ }^{1}$ Federal University of Pampa, campus São Gabriel, Rio Grande do Sul, Brazil - gabrielmarangon@unipampa.edu.br*, matheusmartins.aluno@unipampa.edu.br

${ }^{2}$ Federal University of Uberlândia, Institute of Agrarianl Sciences, Monte Carmelo, Minas Gerais, Brazil - emanuelarnonicost@gmail.com ${ }^{3}$ Federal University of Santa Maria, Department of forest Sciences, Santa Maria, Rio Grande do Sul, Brazil; Federal Technological University of Paraná, Visiting Professor of the Graduate Program in Agroecosystems, Dois Vizinhos, Paraná, Brazil cesarfinger.ufsm@gmail.com

${ }^{4}$ Federal University of Santa Maria, Department of forest Sciences, Santa Maria, Rio Grande do Sul, Brazil schneider.paulorenato@gmail.com

Received for publication: 05/08/2019 - Accepted for publication: 18/09/2020

\begin{abstract}
Resumo
Diagrama de gerenciamento da densidade para povoamentos de Eucalyptus grandis W. Hill. ex Maiden controlados por altura dominante. O presente estudo teve por objetivo elaborar Diagramas de Manejo da Densidade (DMDs) para povoamentos de Eucalyptus grandis W. Hill. ex Maiden com a inclusão da altura dominante. Os dados provêm de parcelas permanentes instaladas nas regiões Centro Oriental Rio-Grandense e Metropolitana de Porto Alegre, Rio Grande do Sul. Os modelos para descrever as relações entre volume médio, número de árvores por hectare, diâmetro médio e altura dominante foram avaliados pelos critérios estatísticos do coeficiente de determinação $\left(\mathrm{R}^{2}\right)$, erro padrão da estimativa em porcentagem (Syx\%) e a análise gráfica dos resíduos em porcentagem. A inclusão da altura dominante no DMD permite melhor controle dos estoques no manejo dos povoamentos em decorrência da forte relação da variável com o sitio de desenvolvimento do povoamento e com a produção florestal.

Palavras-chave: Crescimento, Índice de sítio, Regulação florestal, Produção.
\end{abstract}

\section{Abstract}

Density management diagram for eucalyptus stands controlled by dominant height. The present study aimed to elaborate Density Management Diagrams (DMD) for Eucalyptus grandis W. Hill. ex Maiden stands including the dominant height. Data were obtained from permanent plots installed in the Centro Oriental Riograndense region and the Porto Alegre Metropolitan area, both located in the state of Rio Grande do Sul. The models to describe the relationships between average volume, number of trees per hectare, mean diameter, and dominant height were assessed by the statistical criteria of coefficient of determination $\left(\mathrm{R}^{2}\right)$, standard error of the estimate in percentage (Syx\%), and graphical analysis of residuals. The developed DMD allows for a better control of stocks in the management of stands due to the strong relationship of dominant height with stand development site and forest yield.

Keywords: Growth, Site index, Forest regulation, Yield.

\section{INTRODUCTION}

The analysis of forest growth and yield has become increasingly sophisticated due to the use of new statistical techniques that allow a better description of interrelations of tree site, space, and time. One of the main objectives is to understand how tree growth occurs, which silvicultural treatment must be adopted, and to predict cutting periods and forest yield (CLUTTER et al., 1983).

During the growth process, trees expand their crowns intercepting the highest amount of solar energy as they develop. For this reason, competition increases in as trees age, peaking with the dominance of some trees and the death of others, what benefits the remaining trees (SCHNEIDER, 2009).

Thus, the appropriate density regulation is key to manage a forest stand, allowing the prediction of its future development. The intervention techniques established for the management help maximize productivity and final product quality (RETSLAFF et al., 2016).

One of the most effective methods to plan density in an even-aged stand are density management diagrams (DMDs). They are graphical representations of the development of a stand, illustrated in several formats representing interactions between tree density per hectare and stand variables such as mean diameter, average volume, and dominant height.

DMDs allow to estimate average volume, mean diameter, and height for tree density per hectare in a site at any time during the stand development, with or without thinning. In addition, they include a series of reference curves for different levels of plot occupation (GEZAN et al., 2007), being a useful tool for forest producers due to

FLORESTA, Curitiba, PR, v. 51, n. 1, p. 240-246, jan/mar 2021.

Maragon, G. P. et.al.

ISSN eletrônico 1982-4688

DOI: 10.5380/rf.v51 i1. 68373 
the easiness of application (RETSLAFF et al., 2016) that allows to describe the current stand situation and compare it with pre-established conditions according to the objectives set for the stand.

Density management diagrams have been implemented for several forest species worldwide, with emphasis to Quercus and Carya (U.S. FOREST SERVICE, 1970), Acer sacchrum (SMITH; GIBBS, 1970), for species of Nothofagus (obliqua, alpine and dombeyi) (GEZAN et al., 2007), Pinus sp. (VALBUENA et al., 2016), Hovenia dulcis (SELLE, 2010), Pinus taeda (SCHNEIDER, 2009), Araucaria angustifolia (Bertol.) Kuntze (COSTA et al., 2016) and Eucalyptus grandis (MARANGON, 2017).

As previously mentioned, the present study aimed to develop Density Management Diagrams controlled by the dominant height as an adjuvant in the management of stands of Eucalyptus grandis, in Rio Grande do Sul.

\section{MATERIALS AND METHODS}

The measured Eucalyptus grandis stands are located in two mesoregions in Rio Grande do Sul, the Centro Oriental Riograndense region, which encompasses Santa Cruz do Sul, Lajeado, Estrela, and Cachoeira do Sul; and the Porto Alegre Metropolitan area distributed in the microregions Lagoa dos Patos, Montenegro, Gramado, Canela, Porto Alegre, Osório, and Camaquã (Figure 1). Data were measured in 1193 permanent plots (30 x 20m) located in stands with maximum density, different tree ages and initial spacing $1,0 \times 1,5 \mathrm{~m} ; 1,0 \times 1,5 \mathrm{~m} ; 3,0 \times 1,7 \mathrm{~m}$; $2,3 \times 2,3 \mathrm{~m} ; 2,0 \times 2,0 \mathrm{~m} ; 3,0 \times 1,7 \mathrm{~m} ; 2,3 \times 2,3 \mathrm{~m} ; 2,0 \times 2,0 \mathrm{~m}$; among others.

In each plot, diameter at breast height (d), in cm, with a caliper dendrometer, and height (h), in dm, with a Vertex hypsometer, were measured in order to quantify the number of living and dead trees.

Tree volume was calculated by the Smalian method and volume by area unit was calculated by the sum of extrapolated volumes per hectare, as seen in Table 1.

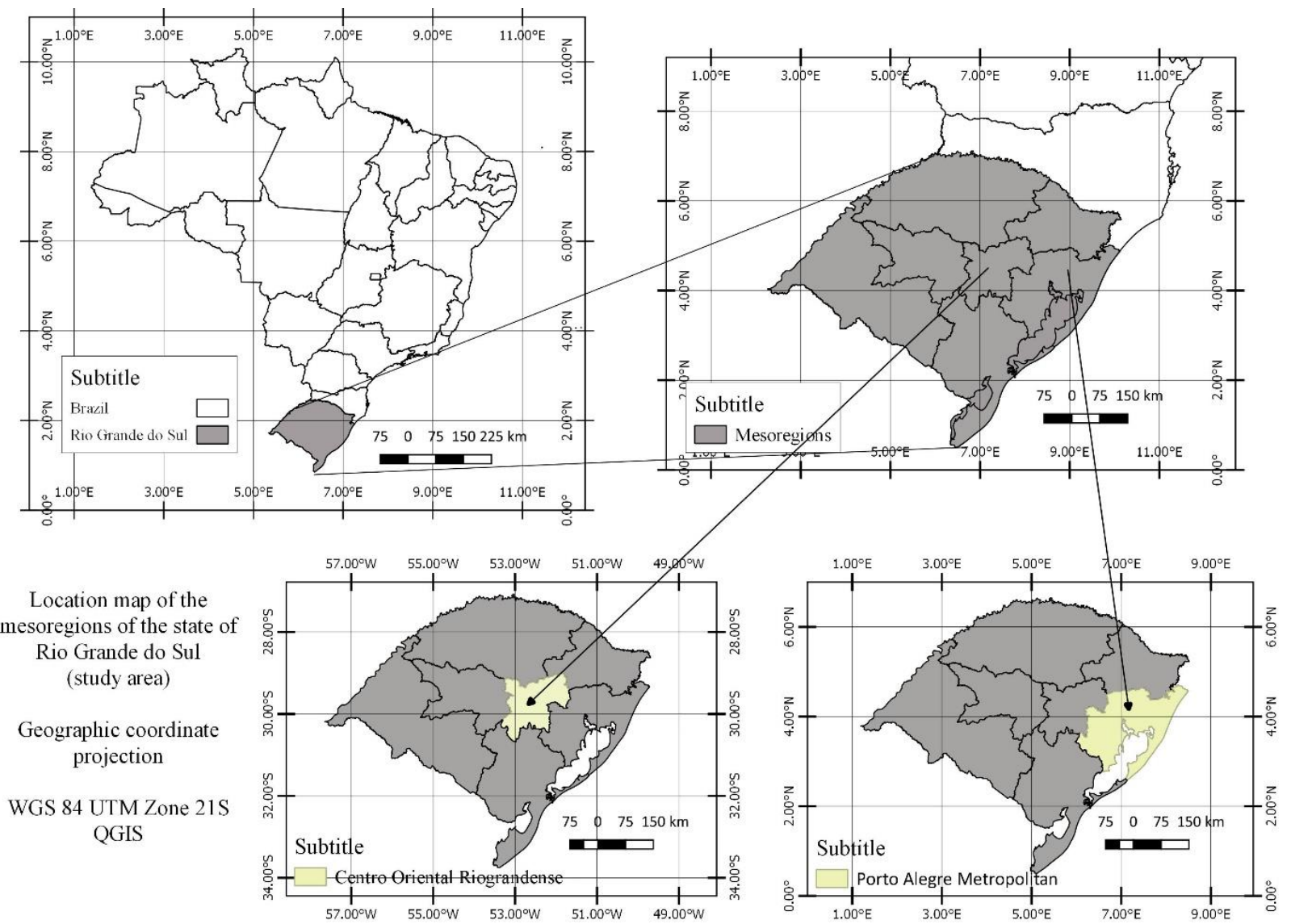

Figure 1: Mesoregions where Eucalyptus grandis stands are located in Rio Grande do Sul, Brazil.

Figura 1: Mesorregiões de localização dos povoamentos de Eucalyptus grandis, no Rio Grande do Sul, Brasil.

The climate in the region is Cfa according to Köppen classification, with average annual temperature 17,9 ${ }^{\circ} \mathrm{C}$, and average annual rainfall 1.826,0 mm (ALVARES et al., 2013). Soils belong to the Rio Pardo mapping unit, which are deep, red coloured in the entire length of the profile, clay, well drained, and deriving from fine-grained siltstone.

FLORESTA, Curitiba, PR, v. 51, n. 1, p. 240-246, jan/mar 2021.

Maragon, G. P. et.al.

ISSN eletrônico 1982-4688

DOI: $10.5380 /$ rf.v51 i1. 68373 
Table 1: Minimum, mean, maximum and standard deviation values of the measured variables in Eucalyptus grandis stands in Rio Grande do Sul, Brazil.

Tabela 1: Valores mínimo, médio, máximo e desvio padrão das variáveis mensuradas em povoamentos de Eucalyptus grandis, no estado do Rio Grande do Sul, Brasil.

\begin{tabular}{ccccc}
\hline Variable & Minimum & Mean & Maximum & StandardDeviation \\
\hline $\mathrm{t}$ & 2,0 & 7,3 & 13,0 & 2,8 \\
$\mathrm{~d}$ & 9,5 & 20,2 & 32,9 & 5,1 \\
$\mathrm{~h}$ & 11,0 & 26,5 & 39,7 & 6,2 \\
$\mathrm{~h}_{100}$ & 13,5 & 30,1 & 42,9 & 6,3 \\
$\mathrm{~V}$ & 0,0360 & 0,4546 & 1,4539 & 0,2832 \\
$\mathrm{G}$ & 10,0 & 26,5 & 53,6 & 8,1 \\
$\mathrm{~N}$ & 292 & 935 & 1975 & 464 \\
$\mathrm{~V}$ & 55,8 & 316,7 & 689,6 & 124,6 \\
\hline
\end{tabular}

Where: $\mathrm{t}=$ age, in years; $\mathrm{d}=$ arithmetic mean diameter, in $\mathrm{cm} ; \mathrm{h}=$ mean height, in $\mathrm{m} ; \mathrm{h}_{100}=$ Assmann mean dominant height, in $\mathrm{m} ; \mathrm{v}=$ average volume, in $\mathrm{m}^{3} ; \mathrm{G}=$ basal area per hectare, in $\mathrm{m}^{2} \cdot \mathrm{ha}^{-1} ; \mathrm{N}=$ number of trees per hectare; $\mathrm{V}=$ volume per hectare, $\mathrm{m}^{3} \cdot \mathrm{ha}^{-1}$.

For the preparation of Density Management Diagrams, the models indicated by Penner et al. (2006) were used. The average volume was used to trace and reference the line of maximum density for the best sites and greater dominant heights. In order to establish the line of maximum density, Line A "Self-thinning" was initially fitted to a regression equation of average volume according to the number of trees as expression of density (model 1), the model subsequently had the intercept value (a) modified, until it overlapped the observed values tending to maximum density.

$$
\ln (\mathrm{v})=\mathrm{a}+\mathrm{b} \cdot \ln (\mathrm{N})
$$

Where: $\mathrm{v}=$ average tree volume, in $\mathrm{m}^{3} ; \mathrm{N}=$ density per hectare, in trees.ha ${ }^{-1} ; \mathrm{a}, \mathrm{b}=$ estimated regression coefficients; ln = natural logarithm.

Line B, "beginning of mortality", and line C, "maximum productivity", were fixed in relation to line A, considering the values of 50,0\% for line B and 40,0\% for line C, with the management line established at a range of $10 \%$. Line D, which describes "crown occupation", was determined for $15,0 \%$ in relation to line A.

For the construction of the series of isometric lines, the average volume was related with the number of trees and the arithmetic mean diameter, used in model 2.

$$
\ln (\mathrm{v})=\mathrm{a}+\mathrm{b} \cdot \ln (\mathrm{d})+\mathrm{c} \cdot \ln (\mathrm{N})
$$

Where: $\mathrm{v}=$ average tree volume, in $\mathrm{m}^{3} ; \mathrm{d}=$ mean diameter, in $\mathrm{cm} ; \mathrm{N}=$ density per hectare, in trees.ha ${ }^{-1} ;$ a.. $\mathrm{c}=$ estimated regression coefficients; $\ln =$ natural logarithm.

Further for the series of isometric lines, the average volume was expressed according to dominant height and number of trees per hectare, model 3.

$$
\mathrm{v}=\frac{1}{\left(\mathrm{a} \cdot \mathrm{h}_{100}{ }^{b}+\mathrm{c} \cdot \mathrm{N} \cdot \mathrm{h}_{100}{ }^{d}\right)}
$$

Where: $\mathrm{v}=$ average tree volume, in $\mathrm{m}^{3} ; \mathrm{h}_{100}=$ Assmann mean dominant height, in $\mathrm{dm} ; \mathrm{N}=$ density per hectare, in trees.ha ${ }^{-1} ;$ a..d = estimated regression coefficients.

Adjustments and statistics were processed with the Statistical Analysis System - SAS V. 9.1 (SAS, 2007), through the procedure PROC REG and PROC NLIN using Marquardt iterative method. The fitted equations were assessed with the statistical criteria: coefficient of determination $\left(\mathrm{R}^{2}\right)$, standard error of the estimate (Syx\%), and graphical analysis of residuals (\%). Models with transformation of the dependent variable had statistics of adjustment $\left(\mathrm{R}^{2}\right)$ and precision $(\mathrm{Syx} \%)$ recalculated to the original unit. For the other calculations and graph development, an Excel worksheet was used. 


\section{RESULTS}

The estimated coefficients and their respective statistics for the fitted models are shown in Table 2.

Table 2: Fitted equations to generate the density management diagram of Eucalyptus grandis stands, Rio Grande do Sul, Brazil.

Tabela 2: Equações ajustadas para gerar o diagrama de manejo da densidade em povoamentos de Eucalyptus grandis, no Rio Grande do Sul, Brasil.

\begin{tabular}{cccc}
\hline Models & Equations & $\mathrm{R}^{2}$ & $\mathrm{Syx} \%$ \\
\hline 1 & $\ln (\mathrm{v})=5,9192-1,0376 \cdot \ln (\mathrm{N})$ & 0,686 & 34,9 \\
2 & $\ln (\mathrm{v})=-12,3793+3,2797 \ln (\mathrm{d})+0,2407 \cdot \ln (\mathrm{N})$ & 0,969 & 11,0 \\
3 & $\mathrm{v}=\frac{1}{\left(1451,7 \cdot \mathrm{h}_{100}{ }^{-2,0810}+3,4867 \cdot \mathrm{N} \cdot \mathrm{h}_{100}{ }^{-2,2488}\right)}$ & 0,930 & 16,5
\end{tabular}

Where: $\mathrm{v}=$ average tree volume, in $\mathrm{m}^{3} ; \mathrm{N}=$ density per hectare, in trees.ha ${ }^{-1} ; \mathrm{d}=$ mean diameter, in $\mathrm{cm} ; \mathrm{h}_{100}=$ Assmann mean dominant height, in $\mathrm{m} ; \mathrm{ln}=$ natural logarithm. *All coefficients of fitted equations were significant $(\alpha=0,05)$.

The estimates obtained with the functions described dimensions represented in the line of average trend and the line of maximum density, projected with a data set in a logarithmic basis. The development of average volume described a negative exponential curve. Regarding tree density per hectare, the average volume decreased with the increase of stand density.

The resulting equations accurately described the dependent variables with regular dispersion of volume residuals yet showing values of more than $40 \%$ distributed as under and over estimation. The three equations of volume related the independent variables in the preparation of the stand density management diagram per site (DMDs) shown in Figure 2.

The equation describing dominant height according to age allows to determine stand height under different yield capacity of sites and, combined with the DMDs, quantify mean diameter, height, average volume and tree density per hectare, in addition to infer about the stand dynamics with the analysis of competition areas in current and future conditions, desirable to achieve the established objectives for the stand management.

Density is regulated near and below the line of maximum density, where imminent tree mortality occurs (traced line, located at $50 \%$ of the line of maximum density). Below this line, density is regulated in the zone of optimal density.

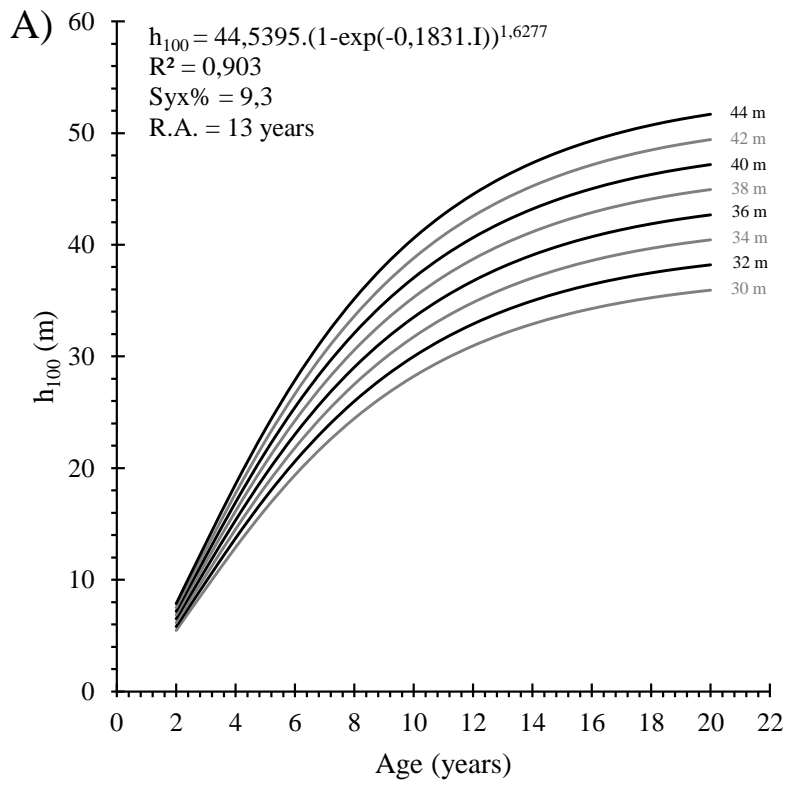

FLORESTA, Curitiba, PR, v. 51, n. 1, p. 240-246, jan/mar 2021. 


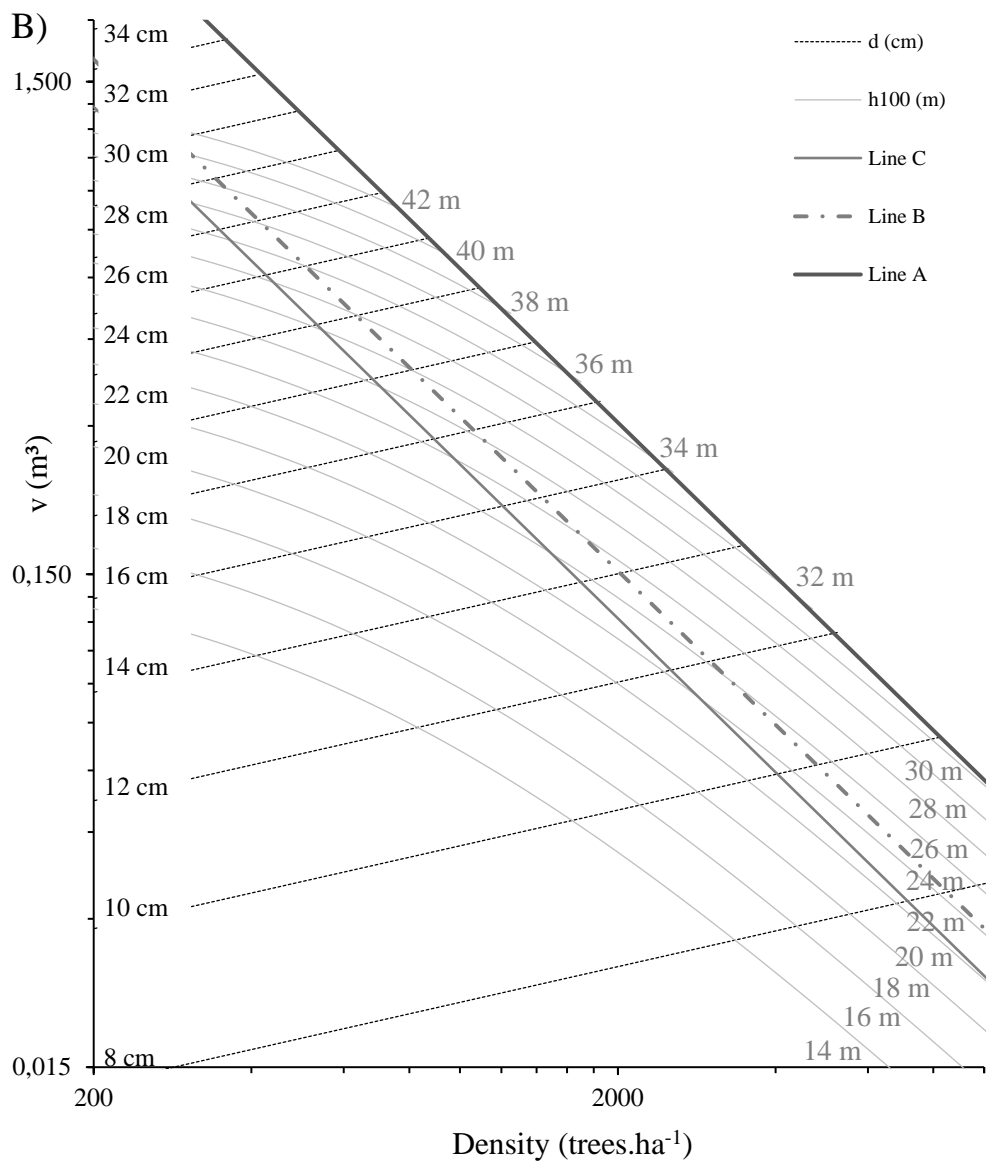

Figure 2: Site index curves (A) and Density Management Diagram (DMD) of Eucalyptus grandis stands (B), in Rio Grande do Sul, Brazil.

Figura 2: Curvas de índice de sítio (A) e Diagrama de Manejo da Densidade (DMD) de Povoamentos de Eucalyptus grandis (B), no Rio Grande do Sul, Brasil.

*Axes of ordinates and abscissa on a logarithmic scale.

* eixos das ordenadas e abscissas em escala logarítmica.

Dominant height as an expression of site quality in the DMD allows a higher accuracy of tree diameter and volume estimates for the same number of trees, whereas the stand mean diameter is overly sensitive to density. Following a height line from right to left, it is evident how diameter decreases as stand density increases.

For a practical use, considering the applicability of Figure 2, a Eucalyptus grandis stand with an approximate density of 1000 trees per hectare, 13 years old, dominant height of $32 \mathrm{~m}$, and mean diameter $20 \mathrm{~cm}$, reaches an optimal management zone between lines b and c, what would result in an average volume of 0,3987 $\mathrm{m}^{3}$. Thus, the use of the diagram allows to identify the appropriate time for planting interventions, which can be brought forward or delayed according to market demands/activities.

\section{DISCUSSION}

The study of stand development with Density Management Diagrams has been performed due to the easiness of field application. Estimates with stand models in maximum density are accurate when using DMDs (BRAVO; MONTERO, 2003), providing the manager with advantages to establish maximum and minimum density levels, knowledge of plot occupation and the decision on the need for thinning and its intensity (VALBUENA et al., 2016).

The complexity of yielding factors (biotic and abiotic) that influence on stand growth was represented in the Density Management Diagram with the variables: diameter, height, number of trees, and volume. The inclusion of dominant height has aggregated to the set, to the plot quality, and is closely related to yield capacity. 
The analysis of the current stand situation and the inference about management actions such as tree density regulation has made possible to predict tree development, volume, and dimensions for future cuttings, as well as the economic analysis of the business.

The management of stands according to the limits materialized by the DMD lines allowed to establish management and forest planning strategies, with the formulation of intervention regimes and yield prognosis considering volume, basal area, mean diameter, and number of trees (MARANGON et al., 2017; 2018).

The knowledge of the interrelations between tree density per hectare and the development of diameter over time are of vital importance, since the aging of a stand increases the mortality rate, what must be avoided through interventions that are proportional to the species growth capacity.

As the actual focus of homogeneous plantings targets wood production for multiple uses and as a greater contribution to biodiversity, forest management is targeted to develop structurally complex stands by adopting strategies that bring forward or delay cuttings, assess the ideal time for thinning for the optimal density regulation, thus increasing business profits.

Density management diagrams for stands with isolines of height provide a graphical tool for the manager to help in the time and length of management operations. The addition of site index and line of maximum density allows to project stand conditions. DMDs can also be used to identify stands that demand thinning aiming to reduce mortality, which is related to high competition, thus maintaining the health of the future stand.

The fitted equations produced accurate estimates, with the fitted coefficients of determination above 0,680 in the models of average volume according to density, and above 0,900 according to diameter, dominant height, and density.

Schneider et al. (2009) confirmed the efficiency of models that express density/diameter and self-thinning relation in stands of Pinus taeda L., with several spacings, maximum density, no thinnings, and measurements performed until 18 years old. To represent the DMD, an equation was selected to estimate the stand average tree volume according to the variables that express stand density and growth. Authors obtained $\mathrm{R}^{2}$ adj. 0,826 for the model of volume according to density; as for the model of volume according to density and diameter $\mathrm{R}^{2}$ adj. 0,984 ; and for two models of volume according to diameter and height $\mathrm{R}^{2}$ adj. 0,988 and 0,983 (non-linear and linear, respectively). One of the models that used height and diameter (non-linear) was selected as optimal, due to showing lower error around $0,146 \mathrm{~m}^{3}$. Therefore, slightly higher results were observed.

Retslaff et al. (2016) developed a DMD to define optimal times for performing thinning and final cut in stands of Pinus taeda L., in Paraná, Brazil. To this end, the Reineke density model was adjusted as well as other equations involving the quadratic mean diameter, stand volume, density, and dominant height. Following the calculation of the quadratic mean diameter through an equation that uses the variables volume and density, volume was calculated, using quadratic mean diameter, dominant height, and density in order to generate the dominant height lines in the DMD. The equation used to estimate volume showed similar results to the present study, with $\mathrm{R}^{2}$ adj. 0,921 and Syx\% 11,04\%.

\section{CONCLUSION}

- Density Management Diagrams are accurate tools to describe the development of stands of Eucalyptus grandis expressing tree density per hectare, mean diameter, and average volume at a given dominant height.

- The use of DMDs allows to plan silvicultural interventions aiming to reach the yield targets for the stand according to site capacity, species managed, economical restrictions, and business demands.

\section{REFERENCES}

ALVARES, C. A.; STAPE, J. L.; SENTElhAS, P. C.; GONÇALVES, J. L. M.; SPAROVEK, G. Köppen's climate classification map for Brazil. Meteorologische Zeitschrift, Stuttgart, v. 22, n. 6, p. 711 - 728, 2013.

BRAVO F., MONTERO G. High-grading effects on Scots pine volume and basal area in pure stands in northern Spain. Annals of Forest Science, v. 60, n. 1, p. 11 - 18, 2003.

CLUTTER, J. L.; FORTSON, J. C.; PIENAAR, L. V.; BRISTER, G. H.; BAILEY, R. L. Timber management: a quantitative approach. New York: John Willey and Sons, 1 ed., 1983, 333 p.

COSTA, E. A.; FINGER, C. A. G.; FLEIG. F. D.; HESS, A. F.; MARANGON, G. P. Dendrograma de manejo da densidade para uma floresta inequiânea de Araucária. Floresta, Curitiba, v. 46, n. 2, p. 173 - 184, 2016.

GEZAN, S. A.; ORTEGA, A.; ANDENMATTEN, E. Diagramas de manejo de densidad para renovales de roble, raulí y coigüe em Chile. Bosque, Valdivia, v. 28, n. 2, p. 97 - 105, 2007. 
MARANGON, G. P.; SCHNEIDER, P. R.; ZIMMERMANN, A. P. L.; LONGHI, R. V.; CAVALLI, J. P. Density management diagramas for stands of Eucalyptus grandis W. Hill RS, Brazil. Revista Árvore, Viçosa, v. 41, n. 1, 2017.

MARANGON, G. P.; SCHNEIDER, P. R.; COSTA, E. A.; OLIVEIRA, T. B. A.; FARIAS, J. A.; FINGER, C. A. G. Economic viability of different management regimes for Eucalyptus grandis W. Hill. Australian Journal of Basic and Applied Sciences, Jordan, v. 12, n. 5, p. 39 - 46, 2018.

PENNER, M.; SWIFT, D. E.; GAGNON, R.; BRISSETTE, J. A stand density management diagram for balsam fir in New Brunswick. The Forestry Chronicle, v. 82, n. 5, p. 700 - 711, 2006.

RETSlAFF, F. A. S.; FILHO, A. F.; MACHADO, S. A.; ARCE, J. E.; JASKIU, E. Diagrama de manejo da densidade para Pinus taeda no Estado do Paraná. Floresta, Curitiba, v. 46, n. 2, p. 185 - 195, 2016.

SAS Institute Inc. SAS/STAT user's guide. Version 8 (computer manual). SAS Institute Inc., Cary. N.C. 1999.

SCHNEIDER, P. S. P.; FLEIG, F. D.; SCHNEIDER, P. R.; FINGER, C. A. G.; CHAVES, D. M. et al. Diagrama de manejo da densidade para povoamento de Pinus taeda L. conduzido sem desbaste. Ciência Florestal, Santa Maria, v. 19, n. 4, p. 433-447, 2009.

SELlE, G. L.; FLEIG, F. D.; SCHNEIDER, P. R.; ALBERNARD, L. A. J.; VUADEN, E.; BRAZ, E. M. Dendrogramas de densidade para Hovenia dulcis Thunberg na Região Central do Estado do Rio Grande do Sul, Brasil. Ciência Florestal, Santa Maria, v. 20, n. 3, p. 477-492, 2010.

SMITH, C.; GIBBS, C. B. A guide to sugarbusch stocking: based on the crown diameter/D.b.h. relationship of open-grown sugar maples. Washington: Forest Service, 1970. 10 p. (Reserarch Paper NE-171).

U.S. FOREST SERVICE. Relation of crown width to tree diameter in same upland hardwood stands of southern Illinois. St. Paul: Southern Forest Experiment Station Library, 1970. 4 p. (Research Note nc-99).

VALBUENA, P.; DEL PESO, C.; G.; BRAVO, F. Stand density management diagrams for two Mediterranean Pine species in eastern Spain. Invest Agrar: Sist. Recur for, Curitiba, v. 17, n. 2, p. 97-107, 2016. 